\title{
PENGARUH PERTUMBUHAN EKONOMI, PENDAPATAN ASLI \\ DAERAH, DANA ALOKASI UMUM, DANA ALOKASI KHUSUS TERHADAP BELANJA MODAL PADA PROVINSI JAWA TENGAH
}

\author{
Siska Puspita Dewi \\ Suyanto* \\ Program Studi Akuntansi Fakultas Ekonomi \\ Universitas Sarjanawiyata Tamansiswa Yogyakarta \\ *iyantsuyanto@gmail.com
}

\begin{abstract}
The purpose of this research is to find out whether Economic Growth, Local Own Revenue, General Alocation Fund, Special Alocation Fund influence the Capital Expenditure at Provinsi Central Java. The analyze method that is used in this research is quantitative method with multiple linier regression with bring about classical assumption test. The variable used in this research are Economic Growth, Local Own Revenue, General Alocation Fund, Special Alocation Fund as independent variable and the Capital Expenditure as dependent variable. Amount of this research population counted 29 Sub-Province and 6 town from year 2007 up to year 2011.

The result proof that Economic Growth, Local Own Revenue, General Alocation Fund, Special Alocation Fund influence significanly and simultaneously the Capital Expenditure of regencies and cities in Central Java. Adjusted R2 expressed that 79,1\% influence given by Independent variables. The rest 20,9\% influence given by other variables is not mentioned in this research model, Partially Regional Own Revenue, and General Alocation Fund, variable influence Capital Expenditure. Economic Growth with PDRB and Special Alocation Fund with actual price have no significant influence to the Capital Expenditure.
\end{abstract}

Keywords: Economic Growth, Regional Own Revenue, General Alocation Fund, Special Alocation Fund and Capital Expenditure.

\section{PENDAHULUAN}

Keadaan geografis Indonesia yang berupa kepulauan berpengaruh terhadap mekanisme Pemerintahan Negara Indonesia. Dengan keadaan geografis yang berupa kepulauan ini menyebabkan pemerintah sulit mengkoordinasi pemerintahan yang ada di daerah. Untuk memudahkan pengaturan atau penataan pemerintahan maka diperlukan adanya suatu sistem pemerintahan yang dapat berjalan secara efisien dan mandiri tetapi tetap terawasi dari pusat Sundari (2011).

Otonomi daerah merupakan hak, wewenang, dan kewajiban daerah otonomi untuk mengatur dan mengurus sendiri urusan pemerintah dan kepentingan masyarakat setempat sesuai dengan peraturan perundangundangan. Hal tersebut sesuai dengan ketentuan umum di UU Otonomi Daerah No. 32 tahun 2004 tentang Pemerintah Daerah yang telah menggantikan UU No. 22 tahun 1999. Pelaksanaan kebijakan pemerintah Indonesia tentang otonomi daerah. UndangUndang No. 25 tahun 1999 tentang Perimbangan Keuangan Pemerintah Pusat dan Pemerintah Daerah menyediakan dasar hukum tentang desentralisasi fiskal, menjelaskan pembagian baru mengenai sumber pemasukan dan transfer antar pemerintah. 
$\begin{array}{cccc} & \text { Belanja modal ini } \\ \text { didasarkan pada kebutuhan daerah akan }\end{array}$ sarana dan prasarana, baik untuk kelancaran pelaksanaan tugas pemerintahan maupun untuk fasilitas publik. Oleh karena itu, dalam upaya meningkatkan kualitas pelayanan publik, pemerintah daerah seharusnya mengubah komposisi belanjanya. Selama ini belanja daerah lebih banyak digunakan untuk belanja rutin yang relatif kurang produktif. Saragih (2003) menyatakan bahwa pemanfaatan belanja hendaknya dialokasikan untuk hal-hal produktif, misal untuk melakukan aktivitas pembangunan. Peran pemerintah di dalam pembangunan adalah sebagai katalisator dan fasilitator, karena pihak pemerintahan yang lebih mengetahui sarana tujuan pembangunan yang akan dicapai. Sebagai pihak katalisator dan fasilitator maka daerah memerlukan sarana dan fasilitas pendukung yang direalisasikan melalui belanja modal guna meningkatkan pelayanan publik (Armayani dalam Halim, 2004).

Akan tetapi melihat fenomena yang terjadi, alokasi belanja modal belum sepenuhnya dapat terlaksana bagi pemenuhan kesejahteraan publik, sebab pengelolaan belanja daerah terutama belanja modal masih belum terorientasi pada publik. Salah satunya disebabkan oleh pengelolaan belanja yang terbentur dengan kepentingan golongan semata. Keefer dan Khemani (dalam Halim dan Abdullah, 2006) menyatakan bahwa adanya kepentingan politik dari lembaga legislatif yang terlibat dalam proses penyusunan anggaran menyebabkan alokasi belanja modal terdistorsi dan sering tidak efektif dalam memecahkan masalah di masyarakat. Padahal menurut Pasal 66 UU No. 33 Tahun 2004 menyatakan bahwa: "Keuangan daerah dikelola secara tertib, taat pada peraturan perundang - undangan, efisien, ekonomis, efektif, transparan, dan bertanggung jawab dengan memperhatikan keadilan, kepatuhan dan manfaat untuk masyarakat". UU tersebut mengisyaratkan kepada Pemda untuk mengelola keuangan daerah terutama belanja modal secara efektif, efisien, dan ekonomis dengan tujuan akhir untuk meningkatkan pelayanan masyarakat. Pernyataan ini sesuai dengan konsep multi - tern expenditure framework (MTEF) yang disampaikan oleh Allen dan Tommasi (dalam Halim dan Abdullah, 2006) yang menyatakan bahwa kebijakan belanja modal harus memperhatikan kemanfaatan (usefulness) dan kemampuan pemerintah daerah (budget capability) dalam pengelolaan asset tersebut dalam jangka panjang. Hal ini berarti bahwa dalam pengelolaan asset tekait dengan belanja pemerintah, dan sumber pendapatan. Pada dasarnya terkandung misi utama sehubungan dengan pelaksanaan otonomi daerah yaitu Mardiasmo (2002): (1)meningkatkan efektifitas dan efisiensi pengelolaan sumber daya daerah, (2)meningkatkan kualitas pelayanan umum dan kesejahteraan masyarakat, (3)memberdayakan dan menciptakan ruang bagi masyarakat untuk ikut serta(berpartisipasi) dalam proses pembangunan.

Alasan Peneliti memilih pemerintahan Kabupaten/Kota di Provinsi Jawa Tengah untuk dijadikan objek penelitian karena Jawa Tengah merupakan provinsi yang luas dan memiliki 35 daerah terdiri dari 29 Kabupaten dan 6 Kota pemerintahan, dan masing- masing memiliki pendapatan dan pengeluaran yang berbeda antara daerah satu dengan daerah yang lainnya. Agar pengeluaran daerah digunakan sesuai dengan rencana maka pemerintah mengeluarkan adanya peraturan perencanaan keuangan tahunan daerah yang ditetapkan berdasarkan peraturan daerah tentang anggaran pendapatan dan belanja daerah.

Penelitian ini mengacu pada penelitian yang telah dilakukan oleh Darwanto dan Yustikasari (2007) yaitu "Pengaruh Pertumbuhan Ekonomi, Dana Alokasi Umum (DAU) dan Pendapatan Asli Daerah (PAD) terhadap Belanja Modal pada Pemerintah Kabupaten/Kota se Jawa-Bali" dengan periode penelitian dari tahun 20042005. Sedangkan peneliti sekarang meneliti

Pendapatan Asli Daerah, Dana Alokasi 
Umum, Dana Alokasi Khusus terhadap Belanja Modal Pada Pemerintah Kabupaten/Kota di Provinsi Jawa Tengah dengan menggunakan periode penelitian dari tahun 2007-2011. Alasan Peneliti mengambil objek penelitian di Jawa Tengah karena Jawa Tengah merupakan Provinsi yang luas dan memiliki 35 daerah terdiri dari 29 Kabupaten dan 6 Kota pemerintahan. Dalam penelitian ini peneliti menambahkan variabel Dana Aloksi Khusus (DAK). Dengan demikian penelitian ini akan menguji apakah PERTUMBUHAN EKONOMI, PENDAPATAN ASLI DAERAH, DANA ALOKASI UMUM, DANA ALOKASI KHUSUS BERPENGARUH TERHADAP BELANJA MODAL.

Rumusan masalah dalam penelitian ini adalah " Bagaimana pengaruh pertumbuhan ekonomi, pendapatan asli daerah, dana alokasi umum, dan dana alokasi khusus terhadap belanja modal pada provinsi jawa tengah".

\section{LANDASAN TEORI}

Menurut Todaro (2003) pertumbuhan ekonomi adalah kenaikan kapasitas dalam jangka panjang dari negara bersangkutan untuk menyediakan berbagai barang ekonomi kepada penduduknya. Menurut Warsito (2001) dalam Damang (2011) Pendapatan Asli Daerah "Pendapatan asli daerah (PAD) adalah pendapatan yang bersumber dan dipungut sendiri oleh pemerintah daerah. Sumber PAD terdiri dari: pajak daerah, restribusi daerah, laba dari badan usaha milik daerah (BUMD), dan pendapatan asli daerah lainnya yang sah". Dana Alokasi Umum (DAU) adalah sejumlah dana yang dialokasikan kepada setiap Daerah Otonom (provinsi/kabupaten/kota) di Indonesia setiap tahunnya sebagai dana pembangunan yang bertujuan sebagai pemerataan kemampuan keuangan antar daerah untuk mendanai kebutuhan Daerah Otonom dalam rangka pelaksanaan desentralisasi (Kafilah Dzikrullah). Dana Alokasi Khusus (DAK) adalah alokasi dari Anggaran Pendapatan dan Belanja Negara kepada provinsi atau kabupaten/kota tertentu dengan tujuan untuk mendanai kegiatan khusus yang merupakan urusan Pemerintah Daerah dan sesuai dengan prioritas nasional (Kafilah Dzikrullah). Menurut PP Nomor 24 Tahun 2005 belanja modal adalah pengeluaran anggaran untuk perolehan aset tetap dan aset lainnya yang memberi manfaat lebih dari satu periode akuntansi.

\section{PERUMUSAN HIPOTESIS \\ Pertumbuhan Ekonomi}

Setiap pemerintahan kabupaten/kota pasti menginginkan adanya pertumbuhan ekonomi di daerah yang ada di bawah perintah atau wewenangnya. Karena pertumbuhan ekonomi menunjukkan kredibilitas/campur tangan/kontribusi pemerintah daerah tersebut dalam menjalankan tugasnya sebagai aparat pemerintahan. Dengan kata lain, pertumbuhan ekonomi adalah bukti nyata hasil usaha/kerja pemerintahan daerah dalam memajukan daerahnya. Pertumbuhan ekonomi dapat diciptakan apabila didukung oleh infrastruktur atau sarana prasarana daerah yang baik. Infrastruktur atau sarana prasarana tersebut bisa didapat dari belanja modal yang dianggarkan pemerintah daerah setiap tahunnya. Bila pertumbuhan ekonomi suatu daerah baik maka berpengaruh pula pada alokasi belanja modal pemerintah daerah tersebut, semakin baik pertumbuhan ekonomi daerah tersebut maka semakin menuntut pemerintahan daerah untuk mengalokasikan belanja modalnya semakin banyak lagi.

Berdasarkan uraian di atas, maka peneliti dapat menentukan hipotesis dalam penelitian ini sebagai berikut:

\section{H1: Pertumbuhan Ekonomi berpengaruh positif terhadap pengalokasian Belanja Modal.}

\section{Pendapatan Asli Daerah}

Pendapatan asli daerah (PAD) adalah pendapatan yang bersumber dan dipungut sendiri oleh 
pemerintah daerah Warsito (2001) dalam Damang (2011). Menurut Herlina Rahman(2005) dalam Damang (2011) Pendapatan asli daerah (PAD) didapatkan dari hasil pajak daerah, hasil retribusi daerah, hasil pengelolaan kekayaan daerah yang dipisahkan dan lain-lain PAD yang sah. Untuk itu, dalam masa desentralisasi seperti ini, pemerintah daerah dituntut untuk bisa mengembangkan dan meningkatkan PADnya masing-masing dengan memaksimalkan sumberdaya yang dimiliki supaya bisa membiayai segala kegiatan penciptaan infrastruktur atau sarana prasarana daerah melalui alokasi belanja modal pada APBD, semakin baik PAD suatu daerah maka semakin besar pula alokasi belanja modalnya.

Berdasarkan uraian di atas, maka peneliti dapat menentukan hipotesis dalam penelitian ini sebagai berikut:

\section{H2: Pendapatan Asli Daerah berpengaruh positif terhadap pengalokasian Belanja Daerah.}

\section{Dana Alokasi Umum}

Dana alokasi umum merupakan salah satu dari Dana Perimbangan yang disediakan oleh pemerintah pusat yang bersumber pada APBN, yang bertujuan untuk memeratakan kemampuan keuangan antar daerah untuk mendanai kebutuhan daerah dalam rangka pelaksanaan desentralisasi (Kafilah Dzikrullah). Pemerintah daerah yang kemampuan keuangannya lemah akan mengandalkan DAU untuk membiayai segala kegiatan pemerintahan, karena DAU juga merupakan salah satu sumber pendanaan bagi daerah dalam pelaksanaan desentralisasi. Oleh karena itu, semakin kecil DAU yang diperoleh semakin kecil pula alokasi belanja modal daerah tersebut.

Berdasarkan uraian di atas, maka peneliti dapat menentukan hipotesis dalam penelitian ini sebagai berikut:

H3: Dana Alokasi Umum berpengaruh positif terhadap pengalokasian Belanja Modal.

\section{Dana Alokasi Khusus}

Dana perimbangan merupakan perwujudan hubungan keuangan antara pemerintah pusat dengan daerah. Salah satu dana perimbangan adalah Dana Alokasi Khusus, DAK merupakan dana yang bersumber dari APBN yang dialokasikan kepada pemerintah daerah untuk membiayai kegiatan khusus yang merupakan urusan daerah dan prioritas nasional. Tujuan DAK untuk mengurangi beban biaya kegiatan khusus yang harus ditanggung oleh pemerintah daerah. Pemanfaatan DAK diarahkan kepada kegiatan investasi pembangunan, pengadaan, peningkatan, perbaikan sarana dan prasarana fisik pelayanan publik dengan umur ekonomis panjang. Dengan diarahkannya pemanfaatan DAK untuk kegiatan tersebut diharapkan dapat meningkatkan pelayanan publik yang direalisasikan dalam belanja modal (Kafilah Dzikrullah).

Berdasarkan uraian di atas, maka peneliti dapat menentukan hipotesis dalam penelitian ini sebagai berikut:

H4: Dana Alokasi Khusus berpengaruh positif terhadap pengalokasian Belanja Modal.

\section{Belanja Modal}

Belanja modal dimaksudkan untuk mendapatkan aset tetap pemerintah daerah yaitu peralatan, bangunan, infrastruktur dan harta tetap lainnya. Secara teoritis ada tiga cara untuk memperoleh aset tetap tersebut yakni dengan membangun sendiri, menukarkan dengan aset tetap lain dan membeli. Namun biasanya cara yang dilakukan dalam pemerintahan adalah dengan cara membeli. Proses pembelian yang dilakukan umumnya melalui sebuah proses lelang atau tender yang cukup rumit.

Menurut PP Nomor 71 Tahun 2010, belanja modal merupakan pengeluaran anggaran untuk perolehan aset tetap dan aset lainnya yang memberi manfaat lebih dari satu periode akuntansi. Belanja modal meliputi belanja modal untuk perolehan tanah, gedung dan bangunan, peralatan dan aset tak berwujud. 
Berdasarkan uraian di atas, maka peneliti dapat menentukan hipotesis dalam penelitian ini sebagai berikut:

\section{H5: Pertumbuhan Ekonomi, Pendapatan Asli Daerah, Dana Alokasi Umum, dan Dana Alokasi Khusus berpengaruh positif terhadap pengalokasian Belanja Modal.}

\section{METODOLOGI PENELITIAN Sifat Penelitian}

Metode penelitian yang digunakan pada penelitian ini adalah metode penelitian kuantitatif. Metode penelitian kuantitatif adalah penelitian menggunakan metode eksperimental untuk menguji hipotesis dengan tujuan menemukan generalisasi dan menekankan pada pengukuran dan analisis hubungan sebab akibat diantara variabel Sekaran (2006).

\section{Populasi, Sampel, dan Teknik Pengambilan Sampel}

Populasi merupakan keseluruhan kelompok orang, kejadian, atau hal minat yang ingin peneliti investigasi Sekaran (2006). Adapun populasi dalam penelitian ini adalah pemerintah daerah kabupaten/kota seJawa Tengah dari tahun 2007-2011.

Sampel adalah sub kelompok atau sebagian dari populasi Sekaran (2006). Berdasarkan karakteristiknya yang dipakai sebagai sampel adalah Kabupaten dan Kota di Jawa Tengah yang memiliki pendapatan daerah aktif, dapat membiayai daerahnya sendiri dimana Kabupaten dan Kota tersebut menerbitkan Laporan Realisasi APBD tahun 2007-20011.

Dari karakteristik di atas dapat dilihat yang termasuk sampel adalah keseluruhan dari populasi. Dengan demikian maka pengambilan sampel dalam penelitian ini menggunakan metode sensus yaitu pemerintah kabupaten dan kota di Jawa Tengah sejumlah 35 kabupaten/kota.

\section{Sumber Data dan Metode Pengumpulan Data}

Data yang dianalisis dalam penulisan ini adalah data sekunder yaitu data yang mengacu pada informasi yang dikumpulkan dari sumber yang telah ada baik data internal maupun eksternal organisasi dan data yang dapat diakses melalui internet, penelusuran dokumen atau publikasi informasi Sekaran (2010).

Pengumpulan data dilakukan untuk memperoleh informasi yang dibutuhkan dalam rangka mencapai tujuan penelitian. Untuk memperoleh data yang relevan sehingga dapat dianalisis, maka diperlukan pengumpulan data dengan metode dokumentasi dimana data yang digunakan dalam penelitian ini dikumpulkan dengan metode dokumentasi dengan mempelajari dokumen-dokumen atau data yang dibutuhkan, dilanjutkan dengan pencatatan dan penghitungan dengan cara menghimpun informasi untuk menyelesaikan masalah berdasarkan data-data yang relevan. Sumber dan penggunaannya dengan data statistik yang didapat dari data eksternal yaitu data yang diperoleh dari BPS (Badan Pusat Statistik). Sifat datanya adalah data kuantitatif yaitu data yang berupa angkaangka, dan bersifat obyektif.

\section{Model Regresi}

Pengujian hipotesis dilakukan dengan menggunakan model analisis regresi berganda bertujuan untuk memprediksi kekuatan pengaruh seberapa variabel independen terhadap variabel dependen Sekaran (1992). 


\section{JURNAL AKUNTANSI VOL.3 NO. 1 JUNI 2015}

adalah:

Model regresi yang digunakan

$$
\begin{aligned}
& \mathrm{Y}=\alpha+B 1 \text { PE_PDRB + B2PAD + B3DAU } \\
& + \text { B4DAK }+e
\end{aligned}
$$

Keterangan:

Y

$(\mathrm{BM})$

$$
\begin{array}{ll}
\alpha & =\text { Konstanta } \\
\beta & = \\
& \text { Slope atau Koefisien } \\
& \text { Regresi }
\end{array}
$$

PE_PDRB = Pertumbuhan Ekonomi

PAD = Pendapatan Asli Daerah

DAU $\quad=$ Dana Alokasi Umum

DAK $\quad=$ Dana Alokasi Khusus

e $\quad=$ error

\section{Analisis Regresi}

Pedoman untuk menerima atau menolak hipotesis sebagai berikut :

\section{Koefisien Determinasi $\left(\mathbf{R}^{2}\right)$}

Koefisien determinasi adalah alat statistik untuk mengetahui besarnya pengaruh variabel independen terhadap variabel dependen. Adapun pedoman untuk melihat hal tersebut adalah dengan melihat koefisien Adjusted R Square X 100\%.

\section{Uji Statistik F}

Membandingkan $\mathrm{F}$ hitung dengan $\mathrm{F}$ tabel Jika $\mathrm{F}$ hitung $<\mathrm{F}$ tabel maka tidak berhasil menolak $\mathrm{H}_{\mathrm{o}}=\mathrm{H}_{\mathrm{o}}$ diterima atau $\mathrm{H}_{1}$ ditolak. Artinya tidak ada pengaruh dari variabel independen terhadap variabel dependen secara simultan. $\mathrm{F}$ hitung $>\mathrm{F}$ tabel maka berhasil menolak $\mathrm{H}_{\mathrm{o}}=\mathrm{H}_{\mathrm{o}}$ ditolak dan $\mathrm{H}_{1}$ diterima. Artinya ada pengaruh dari variabel independen terhadap variabel dependen secara simultan.

\section{Uji Statistik t}

Membandingkan $\mathrm{t}$ hitung dengan $\mathrm{t}$ tabel $\mathrm{t}$ hitung $<\mathrm{t}$ tabel maka tidak berhasil menolak $\mathrm{H}_{\mathrm{o}}=\mathrm{H}_{\mathrm{o}}$ diterima atau $\mathrm{H}_{1}$ ditolak. Artinya tidak ada pengaruh dari variabel independen terhadap variabel dependen secara parsial. $\mathrm{t}$ hitung $>\mathrm{t}$ tabel maka berhasil menolak $\mathrm{H}_{\mathrm{o}}=\mathrm{H}_{\mathrm{o}}$ ditolak dan $\mathrm{H} 1$ diterima. Artinya ada pengaruh dari variabel independen terhadap variabel dependen secara parsial.

\section{HASIL PENELITIAN DAN PEMBAHASAN Statistik Deskriptif Variabel Penelitian}

Tabel 1

\section{Hasil Pengujian Statistik Deskriptif}

\begin{tabular}{lccccc}
\hline \multicolumn{7}{c}{ Descriptive Statistics } \\
\hline Belanja Modal & $\mathrm{N}$ & Minimum & Maximum & Mean & Std. Deviation \\
Pertumbuhan Ekonomi & 175 & .00 & 338.00 & 84.0762 & 77.41982 \\
Pendapatan Asli Daerah & 175 & .00 & 329.000 & 8.5099 & 25.35171 \\
Dana Alokasi Umum & 175 & .0 & 877.5 & 336.466 & 279.5345 \\
Dana Alokasi Khusus & 175 & .00 & 793.27 & 65.5617 & 140.11550 \\
Valid N (listwise) & 175 & & & & \\
\hline
\end{tabular}

Berdasarkan Tabel di atas dapat dilihat bahwa dari jumlah $\mathrm{N}$ sampel sebanyak 175, di mana rata-rata jumlah PE_PDRB (X1) Kabupaten Kota di Jawa
Tengah sebanyak 8.5099 dengan jumlah PE_PDRB terendah 1.04 dan tertinggi sebanyak 329.000 dengan standar deviasi 25.35171 dari rata-rata. Dengan melihat 
angka laju pertumbuhan PE_PDRB pada suatu daerah maka dapat memberikan suatu gambaran bagaimana pembangunan dan pertumbuhan ekonomi yang telah dicapai oleh daerah tersebut.

Rata-rata jumlah PAD Kabupaten Kota di Jawa Tengah sebanyak 47.2681 dengan jumlah PAD terendah sebesar 00 dan tertinggi sebanyak 427.00 dengan standar deviasi 53.48854 dari rata-rata. PAD menggambarkan kemampuan Pemda/Pemko menggali potensi yang yang ada untuk meningkatkan pendapatan daerahnya dalam merealisasikan PAD yang direncanakan guna untuk membiayai daerah pemerintahannya, berdasarkan potensi riil daerah. Secara keseluruhan PAD Kabupaten/Kota Jawa Tengah mengalami kenaikan. Peningkatan Pendapatan Asli Daerah ini merupakan akibat perkembangan pesat pajak daerah dan retribusi daerah.

Dana Alokasi Umum adalah dana yang berasal dari APBN yang dialokasikan dengan tujuan pemerataan kemampuan keuangan antar daerah untuk membiayai kebutuhan pengeluarannya dalam rangka pelaksanaan desentralisasi. Berdasarkan data di atas rata-rata jumlah DAU Kabupaten Kota di Jawa Tengah sebanyak 336.466 dengan jumlah DAU terendah sebesar 0 dan DAU tertinggi sebanyak 877.5dengan standar deviasi 279.5345 dari rata-rata.

Dana Alokasi Khusus (DAK) adalah dana yang bersumber dari pendapatan APBN yang dialokasikan kepada daerah tertentu dengan tujuan untuk membantu mendanai kegiatan khusus yang merupakan urusan daerah dan sesuai dengan prioritas nasional.
Diprioritaskan untuk membantu daerahdaerah dengan kemampuan keuangan di bawah rata-rata nasional, dalam rangka mendanai kegiatan penyediaan sarana dan prasarana fisik pelayanan dasar masyarakat yang telah merupakan urusan daerah. Berdasarkan data di atas rata-rata jumlah DAK Kabupaten Kota di Jawa Tengah sebesar 65.5617 dengan jumlah DAK terendah sebesar 00 dan DAK tertinggi sebanyak 793.27 dengan standar deviasi 140.11550 dari rata-rata.

Belanja modal merupakan belanja pemerintah daerah yang manfaatnya melebihi satu tahun anggaran dan akan menambah aset atau kekayaan daerah dan selanjutnya akan menambah belanja yang bersifat rutin seperti biaya pemeliharaan pada Kelompok Belanja Administrasi Umum. Belanja Modal merupakan belanja daerah yang dilakukan oleh pemerintah daerah diantaranya pembangunan dan perbaikan sektor pendidikan, kesehatan, transportasi, sehingga masyarakat juga menikmati manfaat dari pembangunan daerah. Tersedianya infrastruktur yang baik diharapkan dapat menciptakan efisiensi dan efektivitas di berbagai sektor, produktivitas masyarakat diharapkan menjadi semakin tinggi dan pada gilirannya terjadi peningkatan pertumbuhan ekonomi. Ratarata anggaran belanja modal sebesar 84.0762 dengan jumlah anggaran belanja modal terendah sebesar 00 dan tertinggi sebesar 338.00 dengan standar deviasi 77.41982 dari rata-rata.

\section{Uji Asumsi Klasik}

Uji Multikolonieritas

Tabel 2

Hasil Pengujian Uji Multikolonieritas

\begin{tabular}{|c|c|c|}
\hline \multirow{2}{*}{ Model } & \multicolumn{2}{|c|}{ Collinearity Statistics } \\
\hline & Tolerance & VIF \\
\hline \multicolumn{3}{|l|}{ (Constant) } \\
\hline Pertumbuhan Ekonomi & .984 & 1.016 \\
\hline Model & \multicolumn{2}{|c|}{ Collinearity Statistics } \\
\hline
\end{tabular}




\section{JURNAL AKUNTANSI VOL.3 NO. 1 JUNI 2015}

\begin{tabular}{lcc}
\cline { 2 - 3 } & Tolerance & VIF \\
\hline Dana Alokasi Umum & .508 & 1.968 \\
Dana Alokasi Khusus & .852 & 1.174 \\
\hline
\end{tabular}

Sumber: Data Diolah, 2014

Berdasarkan Tabel di bawah ini, tidak terdapat satu variabel yang mempunyai nilai $\mathrm{VIF}>10$. Artinya kelima variabel independen tersebut tidak terdapat hubungan multikolonearitas dan dapat digunakan untuk memprediksi belanja modal selama periode pengamatan

2007-2011.

\section{Uji Autokolerasi}

\section{Tabel 3}

Hasil pengujian Uji Autokorelasi

\begin{tabular}{cccccc}
\multicolumn{7}{c}{ Model Summary $^{\mathbf{b}}$} \\
\hline Model & $\mathrm{R}$ & R Square & Adjusted R Square & $\begin{array}{c}\text { Std. Error of the } \\
\text { Estimate }\end{array}$ & Durbin-Watson \\
\hline 1 & $.892^{\mathrm{a}}$ & .796 & .791 & 35.41110 & 1.848 \\
\hline
\end{tabular}

a. Predictors: (Constant), Pertumbuhan Ekonomi, Pendapatan Asli Daerah, Dana Alokasi Khusus,

Dana Alokasi Umum

b. Dependent Variable: Belanja Modal

Sumber: Data Diolah, 2014

Tampilan output SPSS berikut ini menunjukkan besarnya nilai Durbin Watson sebesar 1.848. Nilai DW menurut tabel dengan $\mathrm{n}=175$ dan $\mathrm{k}=4$ didapat angka $\mathrm{dL}=$
1,7062 dan $\mathrm{Du}=1,7996$.Oleh karena nilai DW hitung > dU, maka dapat disimpulkan tidak terdapat autokolerasi antar residual.

\section{Uji Heteroskedastisitas}

\section{Gambar 1}

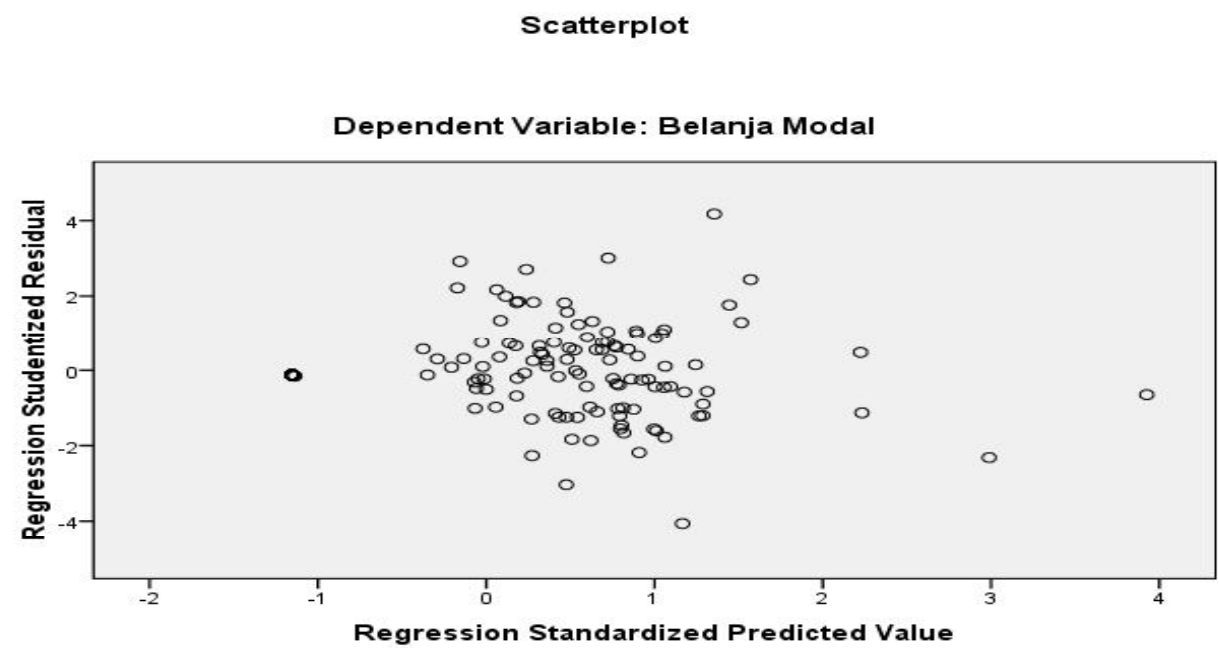


Grafik scatterplots terlihat titik-titik Disimpulkan bahwa tidak terjadi menyebar secara acak baik diatas maupun heteroskedastisitas pada model regresi. dibawah angka 0 pada sumbu $Y$.

\section{Uji Normalitas}

\section{Gambar 2}

\section{P-P Plot Standardized Residual}

\section{Normal P-P Plot of Regression Standardized Residual}

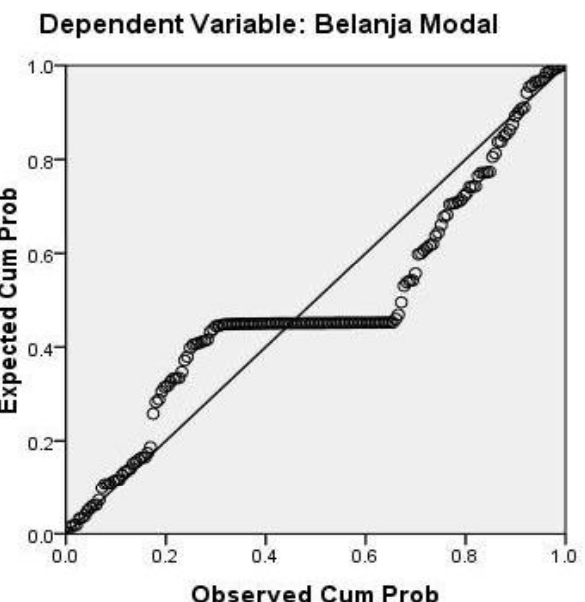

Berdasrkan gambar P-P plot menyebar disekitar garis diagonal dan standardized residual menunjukan pola data mengikuti arah garis diagonal, maka model terdistribusi normal, terlihat titik-titik regresi memenuhi persamaan normalitas.

\section{Analisis Regresi}

\section{Tabel 4}

\section{Hasil uji statistik t}

Coefficients $^{a}$

\begin{tabular}{lccccc}
\hline \multirow{2}{*}{ Model } & \multicolumn{2}{c}{$\begin{array}{c}\text { Unstandardized } \\
\text { Coefficients }\end{array}$} & $\begin{array}{c}\text { Standardized } \\
\text { Coefficients }\end{array}$ & $\mathrm{T}$ & Sig. \\
\cline { 2 - 5 } & $\mathrm{B}$ & Std. Error & Beta & & \\
\hline 1(Constant) & 4.241 & 4.246 & & .999 & .319 \\
Pertumbuhan Ekonomi & .030 & .107 & .010 & .285 & .776 \\
Pendapatan Asli Daerah & .527 & .070 & .364 & 7.547 & .000 \\
Dana Alokasi Umum & .182 & .013 & .655 & 13.473 & .000 \\
Dana Alokasi Khusus & -.098 & .021 & -.177 & -.4703 & .000 \\
\hline
\end{tabular}

a. Dependent Variable: Belanja Modal

Sumber: Data Diolah, 2014 
Selain itu berdasarkan pada hasil uji-t tersebut diperoleh persamaan regresi. Persamaan regresi tersebut adalah sebagai berikut:

$\mathrm{Y}=4.241+0.30 \mathrm{PE}+0.527 \mathrm{PAD}+0.182 \mathrm{DAU}-$ 0.98 DAK

Dari persamaan regresi linier berganda dapat dijelaskan:

- $\quad$ Konstanta $(\alpha)$ sebesar 4.241

- Koefisien regresi untuk pertumbuhan ekonomi sebesar 0,30 artinya bahwa setiap perubahan satu satuan pertumbuhan ekonomi (PE), maka Belanja Modal akan mengalami kenaikan sebesar $0,30 \%$.
Koefisien regresi untuk pendapatan asli daerah sebesar 0,527 artinya bahwa setiap perubahan satu satuan pendapatan asli daerah (PAD), maka Belanja Modal akan mengalami kenaikan sebesar 0,527\%.

- Koefisien regresi untuk dana alokasi umum sebesar 0,182 artinya bahwa setiap perubahan satu satuan dana alokasi umum (DAU), maka Belanja Modal akan mengalami kenaikan sebesar $0,182 \%$.

- Koefisien regresi untuk dana alokasi khusus sebesar 0,98 artinya bahwa setiap perubahan satu satuan dana alokasi khusus (DAK), maka Belanja Modal akan mengalami penurunan sebesar $0,98 \%$.

\section{Analisis Hipotesis}

\section{Tabel 5}

\section{Hasil Pengujian Uji Parsial}

\begin{tabular}{|c|c|c|c|c|c|}
\hline \multicolumn{6}{|c|}{ Coefficients $^{a}$} \\
\hline \multirow{3}{*}{ Model } & \multirow{2}{*}{\multicolumn{2}{|c|}{$\begin{array}{c}\text { Unstandardized } \\
\text { Coefficients }\end{array}$}} & \multirow{3}{*}{$\begin{array}{c}\begin{array}{c}\text { Standardized } \\
\text { Coefficients }\end{array} \\
\text { Beta }\end{array}$} & \multirow{3}{*}{$\mathrm{T}$} & \multirow{3}{*}{ Sig. } \\
\hline & & & & & \\
\hline & $\mathrm{B}$ & Std. Error & & & \\
\hline 1 (Constant) & 4.241 & 4.246 & & .999 & .319 \\
\hline Pertumbuhan Ekonomi & .030 & .107 & .010 & .285 & .776 \\
\hline Pendapatan Asli Daerah & .527 & .070 & .364 & 7.547 & .000 \\
\hline Dana Alokasi Umum & .182 & .013 & .655 & 13.473 & .000 \\
\hline Dana Alokasi Khusus & -.098 & .021 & -.177 & -.4703 & .000 \\
\hline
\end{tabular}

a. Dependent Variable:

Belanja Modal

Dari tabel di atas dapat diketahui bahwa pertumbuhan ekonomi mempunyai nilai thitung sebesar 0.285 sedangkan ttabel sebesar 1.974017 sehingga thitung < ttabel dengan probabilitas signifikan untuk variabel pertumbuhan ekonomi 0.776 lebih besar dari taraf signifikansi 0.05 . berdasarkan hal ini

sehingga dapat disimpulkan bahwa secara parsial pertumbuhan ekonomi berpengaruh negatif dan tidak signifikan terhadap belanja modal, ini disebabkan oleh pertumbuhan ekonomi mengalami peningkatan tetapi belanja modal menurun, karena pertumbuhan ekonomi tercipta dari infrastruktur atau sarana dan prasarana yang baik, infrastuktur atau sarana dan prasarana berasal dari belanja modal yang baik sehingga dapat meningkatkan pertumbuhan ekonomi, sedangkan pada penelitian ini pemerintah daerah tidak mengalokasikan belanja modalnya secara tidak tetap sasaran.

Pendapatan asli daerah mempunyai nilai thitung sebesar 7.547 sedangkan tabel sebesar 1.974017 sehingga thitung > t tabel dengan probabilitas signifikansi untuk variabel pertumbuhan ekonomi 0.000 lebih kecil dari tarif signifikansi 0.05 . berdasarkan 
hal ini maka Ho2 ditolak dan $\mathrm{H} \alpha 2$ diterima, sehingga dapat disimpulkan bahwa secara parsial pendapatan asli daerah berpengaruh positif dan signifikan terhadap belanja modal, ini disebabkan karena PAD merupakan sumber pendapatan yang diperoleh dari daerah yang digunakan untuk membiayai penyelenggaraan pemerintahan dan pembangunan daerah, sehingga jika PAD meningkat maka dana yang dimiliki oleh Pemerintah Daerah akan lebih tinggi dan tingkat kemandirian daerah akan meningkat pula, Pemerintah Daerah akan berinisiatif untuk lebih meningkatkan belanja modalnya (Sumarni)

Dana alokasi umum mempunyai nilai thitung sebesar 13.473 sedangkan ttabel sebesar 1.974017 sehingga thitung > t tabel dengan probabilitas signifikansi untuk variabel ukuran perusahaan 0.000 lebih besar dari taraf signifikansi 0.05 . berdasarkan hal ini maka $\mathrm{Ho}_{3}$ ditolak dan $\mathrm{H}_{3}$ diterima, sehingga dapat disimpulkan bahwa secara parsial dana alokasi umum berpengaruh positif dan signifikan terhadap belanja modal, ini disebabkan karena dengan adanya transfer DAU dari Pemerintah Pusat maka
Pemerintah Daerah bisa mengalokasikan pendapatannya untuk membiayai Belanja Modal.

Dana alokasi khusus mempunyai nilai thitung sebesar -4.703 sedangkan ttabel sebesar 1.974017 sehingga thitung < ttabel dengan probabilitas signifikansi untuk variabel ukuran perusahaan 0.000 lebih besar dari taraf signifikansi 0.05 . berdasarkan hal ini maka $\mathrm{Ho}_{4}$ diterima dan $\mathrm{Ho}_{4}$ ditolak, sehingga dapat disimpulkan bahwa secara parsial dana alokasi khusus berpengaruh negatif dan signifikan terhadap belanja modal, ini disebabkan karena besarnya dana alokasi khusus relatif kecil dibandingkan dengan dana perimbangan lainnya, seperti DAU dan DBH sehingga peningkatan DAK hanya menggandalkan pertumbuhan ekonomi, pertumbuhan ekonomi tercipta dari insfrastruktur atau sarana dan prasarana yang baik, insfrastuktur atau sarana dan prasarana didapat dari belanja modal, sedangkan dalam penelitian ini pemerintah daerah tidak mengalokasikan belanja modalnya dengan baik karena digunakan untuk memenuhi kebutuhan perorangan.

Tabel 6

Hasil Pengujian Uji Simultan

\begin{tabular}{lccccc}
\multicolumn{5}{c}{ ANOVA $^{\mathrm{b}}$} \\
\hline Model & Sum of Squares & Df & Mean Square & F & Sig. \\
\hline Regression & 829755.273 & 4 & 207438.818 & 165.429 & $.000^{\mathrm{a}}$ \\
Residual & 213170.791 & 170 & 1253.946 & & \\
Total & 1042926.064 & 174 & & & \\
\hline
\end{tabular}

a. Predictors: (Constant), Dana Alokasi Khusus, Pertumbuhan Ekonomi, Dana Alokasi Umum,

Pendapatan Asli Daerah

b. Dependent Variable: Belanja Modal

Sedikitnya ada satu variabel pertumbuhan ekonomi, pendapatan asli alokasi khusus yang berpengaruh signifikan daerah, dana alokasi umum, dan dana terhadap belanja modal 


\begin{tabular}{|c|c|c|c|c|c|}
\hline \multicolumn{6}{|c|}{$\begin{array}{c}\text { Tabel } 7 \\
\text { Hasil Pengujian Koefisien Determinasi } \\
\text { Model Summary }\end{array}$} \\
\hline Model & $\mathrm{R}$ & R Square & $\begin{array}{l}\text { Adjusted R } \\
\text { Square }\end{array}$ & $\begin{array}{c}\text { Std. Error of the } \\
\text { Estimate }\end{array}$ & Durbin-Watson \\
\hline 1 & $.892^{\mathrm{a}}$ & .796 & .791 & 35.41110 & 1.848 \\
\hline
\end{tabular}

a. Predictors: (Constant), Pertumbuhan Ekonomi, Pendapatan Asli Daerah, Dana Alokasi Khusus,

Dana Alokasi Umum

b. Dependent Variable: Belanja Modal

Dari tabel diatas diketahui bahwa nilai adjusted $\mathrm{R}$ sebesar 0,791 yang berarti bahwa $79,1 \%$ belanja modal dipengaruhi oleh pertumbuhan ekonomi, pendapatan asli daerah, dana alokasi umum, dan dana alokasi khusus, sedangkan sisanya 20,9\% kemungkinan dipengaruhi oleh variabel lain diluar penelitian ini.

\section{SIMPULAN}

Berdasarkan analisis data dan hasil pengujian hipotesis pada penelitian ini dapat disimpulkan bahwa secara simultan pertumbuhan ekonomi, pendapatan asli daerah, dana alokasi umum, dan dana alokasi khusus berpengaruh terhadap belanja modal, dan sedangkan secara parsial pendapatan asli daerah dan dana alokasi umum berpengaruh terhadap belanja modal, sedangkan Pertumbuhan Ekonomi dan dana alokasi khusus tidak berpengaruh terhadap belanja modal.

Kemampuan persamaan regresi dalam penelitian ini untuk menjelaskan besarnya variasi yang terkait pada variabel terkait adalah sebesar $79,1 \%$, sementara $20,9 \%$ dijelaskan oleh variabel lain yang tidak digunakan dalam persamaan regresi ini.

\section{KETERBATASAN}

Penelitian ini hanya membahas mengenai pengaruh pertumbuhan ekonomi, pendapatan asli daerah, dana alokasi umum, dan dana alokasi khusus terhadap belanja modal daerah Kabupaten / Kota di Jawa
Tengah. Sampel yang digunakan diambil selama periode tahun 2007-2011.

Penelitian ini tidak membahas kebijakan pemerintah dalam penyusunan anggaran Belanja Modal.

\section{SARAN}

Berdasarkan kesimpulannya, maka penelitian selanjutnya sebaiknya: 1) Variabel yang digunakan dalam penelitian yang akan datang diharapkan agar lebih lengkap dan bervariasi dengan menambah variabel independen yang lebih baik, antara lain: belanja bagi hasil dan bantuan keuangan, belanja tidak tersangka; 2) Bagi peneliti selanjutnya disarankan untuk memperbanyak sensus yang digunakan agar hasilnya lebih baik terhadap populasi yang dipilih dan mengambil sampel selain Kabupaten / Kota di Propinsi Jawa Tengah periode tahun 20072011.

\section{DAFTAR PUSTAKA}

Darwanto dan Yustikasari, Yulia. 2007. Pengaruh Pertumbuhan Ekonomi, Pendapatan Asli Daerah dan Dana Alokasi Umum terhadap Pengalokasian Anggaran Belanja Modal. Jurnal Akuntansi dan Keuangan Sektor Publik, Vol 08 No 01. February 2007. BPFE UGM. Yogyakarta.

Halim, Abdul \& Syukriy Abdullah. 2004. Pengaruh Dana Alokasi Umum dan Pendapatan Asli Daerah Terhadap 
Belanja Pemda: Studi Kasus Kabupaten dan Kota di Jawa dan Bali. Jurnal Ekonomi STEI No.2/Tahun XIII/25.

2006. Hubungan dan Masalah Keagenan di Pemerintahan Daerah: Sebuah Peluang Penelitian Anggaran dan Akuntansi. Jurnal Akuntansi Pemerintah 2(1): 53-64. Hair, et al. 1988. Multivariate Data Analisys, Fifth Edition, PrenticeHall International. New Jersey.

Mardiasmo. 2002. Otonomi dan Manajemen Keuangan Daerah. Andi. Yogyakarta.

Undang-Undang Republik Indonesia Nomor 22 Tahun 1999 tentang Pemerintah Daerah. Departemen Komunikasi dan Informatika. Jakarta.

Undang-Undang Republik

Indonesia Nomor 32 Tahun 2004 tentang Pemerintah Daerah. Departemen Komunikasi dan Informatika. Jakarta.

Undang-Undang Republik

Indonesia Nomor 33 Tahun 2004 tentang Perimbangan Keuangan antara pemerintah pusat dan pemerintah daerah, Departemen Komunikasi dan Informatika. Jakarta.

Undang-Undang Republik Indonesia Nomor 25 Tahun 1999 tentang Perimbangan Keuangan antara Pemerintah Pusat dan Daerah.

\section{Peraturan Pemerintah}

Republik Indonesia Nomor 24 Tahun 2005 tentang Standar Akuntansi Pemerintahan.

. Peraturan Pemerintah Republik Indonesia Nomor 71
Tahun 2010 tentang Standar Akuntansi Pemerintahan.

Saragih, Juli Panglima. 2003. Desentralisasi Fiskal dan Keuangan Daerah dalamOtonomi. Penerbit Ghalia Indonesia. Jakarta.

Sekaran, Uma. 1992. Research Methods for Business (A Skill Building Approach). Second Edition. John Wiley \& Sons. New York. Sidik, Machfud, Raksaka Mahi, Robert Simanjuntak dan Bambang Brodjonegoro. 2002. Dana Alokasi Umum: Konsep, Hambatan dan Prospek di Era Otonomi Daerah. Penerbit Buku Kompas. Jakarta.

Sekaran, Uma. 2006. Metode Penelitian untuk Bisnis. Jakarta. Salemba Empat.

Sekaran, Uma. 2010. Metode Penelitian untuk Bisnis. Jakarta. Salemba Empat.

Sundari, Mita. 2011. Pengaruh Dana Alokasi Umum, dan Pendapatan Asli Daerah Terhadap Belanja Daerah Sebelum dan Saat Otonomi Daerah Di Kabupaten/Kota Provinsi Jawa Tengah. Universitas Ahmad Dahlan, Yogyakarta.

Sumarni, Saptaningsih. Pengaruh Pendapatan Asli Daerah, Dana Alokasi Umum. Pdf.

Todaro, Michael P. And Smith Stephen C., 2003. Economic Development Eight Edition. United Kingdom, Pearson Education Limited.

www.bps.go.id/jawatengah.

www.depkeu.djpk.go.id.

http://abdoel-

azys.blogspot.com/2014/01/makalah -dana-alokasi-umum-dan-dana.html

http://www.negarahukum.com/hukum/penda patan-asli-daerah.html 